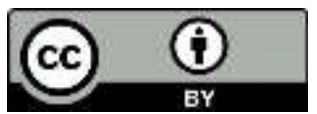

\title{
SURFANDO NAS ONDAS DO SENHOR: JUVENTUDE EVANGÉLICA E MÍDIA NO BRASIL (ANOS 2000-2010)
}

Surfing in the waves of the Lord: Evangelical youth and the media in Brazil (2000-2010)

Karina Kosicki Bellotti

Docente do Departamento de História e do Programa de Pós-Graduação em História da Universidade Federal do Paraná.

karinakbellotti@gmail.com

\begin{abstract}
RESUMO: Este artigo explora as relações entre juventude evangélica na sua diversidade e os variados usos da mídia, que compreendem diferentes estratégias direcionadas à juventude evangélica no Brasil. Analisamos tanto iniciativas articuladas por igrejas com o intento de atrair jovens para seus templos, quanto ações de grupos juvenis em organizações paraeclesiásticas e mocidades ligadas a igrejas, dentro do recorte temporal dos anos 2000 a 2010. Quais as relações que os jovens evangélicos têm mantido com suas instituições religiosas? Os usos da mídia, em especial as mídias digitais, têm interferido nas atividades destes jovens dentro e fora de suas igrejas? Observa-se que, em alguns casos, os jovens evangélicos encontraram na mídia um canal de expressão que nem sempre lhes é conferido no interior de suas igrejas, principalmente nas mais tradicionais. Contudo, ao mesmo tempo, existem igrejas que investem nas novas tecnologias de comunicação a fim de atrair e manter a juventude como seus membros ativos. Utilizamos como arcabouço teórico a História Cultural e os Estudos Culturais, para abordar as relações entre religião, mídia, cultura e identidade.
\end{abstract}

Palavras-chave: Juventude, protestantismo, pentecostalismo, mídia, História Cultural.

ABSTRACT: This article explores the relations between Evangelical youth in its diversity, and the varied uses of the media, which implies different strategies directed to the Evangelical youth in Brazil. I analyse initiatives articulated by churches with the intent of attracting young people to their temples, and actions of youth groups in para-church groups, and church youths, during the decades of 2000 and 2010. What are the relations that the Evangelical youth have been maintained with their religious institutions? Have the uses of the media, especially the digital media, interfered in the activities of these young people within and outside the church? One observes that, in some cases, the young Evangelicals have found in the media a channel of expression that is barely given by their churches, mainly in the most traditional ones. However, at the same time, there are churches that had invested in the new technologies of communication in order to attract and maintain the youth as active members. I use as theoretical framework the Cultural History and the Cultural Studies to approach theses relations between religion, media, culture, and identity.research seeking to relate the religiosity of this region with problems of medieval culture.

Key-words: Youth, Protestantism, Pentecostalism, media, Cultural History.

\footnotetext{
${ }^{1}$ Este texto é uma adaptação atualizada do paper originalmente apresentado no XXX Congresso da LASA (Latin American Studies Association), que ocorreu em San Francisco, California, em maio de 2012. A participação no congresso foi patrocinada com auxílio da CAPES (Coordenação de Aperfeiçoamento de Pessoal de Nível Superior).
} 


\section{Introdução}

Este estudo explora as relações entre juventude evangélica na sua diversidade e os variados usos da mídia, que compreendem diferentes estratégias direcionadas à juventude evangélica no Brasil articuladas tanto por igrejas com o intento de atrair jovens para seus templos, quanto por grupos juvenis por meio de organizações paraeclesiásticas, mocidades ligadas a igrejas. Quais as relações que os jovens evangélicos têm mantido com suas instituiçõos religiosas? Os usos da mídia, em especial as mídias digitais, têm interferido nas atividades destes jovens dentro e fora de suas igrejas?

Tem se observado que, em alguns casos, os jovens evangélicos encontraram na mídia um canal de expressão que nem sempre lhes é conferido no interior de suas igrejas, principalmente nas mais tradicionais. Contudo, ao mesmo tempo, existem igrejas - recentes e tradicionais- que inventem nas novas tecnologias de comunicação a fim de atrair e manter a juventude como seus membros ativos.

As pesquisas de Leonildo Campos (1997) e Magali Cunha (2007) já demonstraram nos anos que igrejas neopentecostais imprimiram uma significativa transformação de paradigma para o campo religioso brasileiro ao empregar elementos empresariais na hierarquia eclesiástica e na evangelização, aliados ao intenso uso de modernos meios de comunicação. Antes disso, desde os anos 1950 tem ocorrido a construção de um supermercado cultural evangélico, intensificado a partir dos anos 1990, que fomentou dois fenômenos evangélicos paralelos em um contexto de competição religiosa: primeiro, a mistura de fronteiras denominacionais devido ao investimento em produtos culturais para a família e a infância oferecidos por empresas evangélicas não denominacionais, almejando um público cristão amplo. Segundo, a consolidação de fronteiras denominacionais e identitárias em igrejas que buscam a diferenciação dentro deste campo competitivo, quando não se colocam à parte de tal competição, tais como presbiterianos, metodistas, luteranos, alguns ramos dos batistas, a Congregação Cristã no Brasil, dentre outras.

Por sua vez, a juventude inscreve-se neste cenário como um alvo em potencial para a renovação deste campo religioso. Para as igrejas mais antigas, existe o desafio de manter os jovens em suas comunidades, após passarem sua infância atuando na igreja junto com sua família. Para as igrejas mais recentes, há o desafio de atrair os jovens 
com a oferta de maiores oportunidades e espaços para engajamento. As respostas desenvolvidas pelas igrejas até o momento tem se mostrado variadas. Por exemplo, a centenária Assembleia de Deus Ministério de Belém, dentro da sua variedade, em geral propõe um ambiente controlado para a expressão juvenil, o que gera descontentamento e saída de jovens para outras instituições mais identificadas com a membresia juvenil, como as pentecostais Sara Nossa Terra, Bola de Neve Church e Renascer em Cristo.

Nesta pesquisa temos investigado os usos da mídia por e para jovens evangélicos: esses usos têm auxiliado no engajamento desses jovens dentro e fora de suas igrejas? Se positivo, de que forma e até que ponto? Nossa maior fonte foi a internet, em especial as redes sociais, tais como o Orkut e Facebook, websites e blogs mantidos por jovens evangélicos. Uma advertência precisa ser dita sobre este tipo de pesquisa: em se tratando de um trabalho de história contemporânea envolvendo meios de comunicação, as marcas do tempo tornam-se mais pronunciadas, devido à veloz obsolescência dos meios digitais. Por exemplo, atualmente, em 2012, a rede social Facebook ultrapassou em popularidade a rede social Orkut, que por sua vez agregou mais brasileiros e indianos do que norte-americanos. No período em que realizei o levantamento de dados, em 2010, o Orkut, datado para ser fechado em outubro de 2014, ainda continuava em alta, abrigando diversos fóruns de discussão que o Facebook ainda não logrou realizar. Enquanto base de dados para estudos de recepção o Orkut foi uma fonte interessante, agregando em seus poucos anos de existência uma grande quantidade de troca de mensagens que permitem o cientista social vislumbrar debates e opiniões que não necessariamente reverberam o que os grandes meios de comunicação anunciam.

Além disso, os websites e os blogs criados por jovens evangélicos oferecem diversos tipos de material: de reflexões teológicas a agenda de eventos; de críticas ao campo evangélico a tentativas de emular ferramentas digitais seculares, como o Facebook (Facecristão) e as compras coletivas. Nesse sentido, observo as formas como a mídia tem sido usada tanto para fortalecer as fronteiras culturais quanto para misturar identidades.

Para tal, utilize a abordagem teórica da História Cultural, o que significa considerar as crenças, práticas, representações e discursos religiosos como construções históricas advindas tanto das instituições quanto dos indivíduos. No que se refere à era contemporânea ocidental, a religião é também sujeita à secularização, à modernidade, à 
urbanização e à destradicionalização (HELLAS, MORRIS, LASH, 1996). Portanto, uma abordagem cultural sobre a religião implica estudar não somente o papel das instituições religiosas para a manutenção de sua coesão, mas também os esforços de inserção social e cultural em um amplo, competitivo e plural campo religioso. Além disso, a perspectiva histórica cultural enfatiza as ações dos sujeitos, sejam afiliados ou não a tradições religiosas, na preservação e/ou na transformação das identidades e pertenças religiosas no seu cotidiano, no qual imaginários religiosos são refeitos e imbricados com outras instâncias sócio-culturais (BELLOTTI, 2011a).

A abordagem cultural relativa à comunicação inspira-se nas considerações dos historiadores culturais franceses Michel de Certeau (1988) e Roger Chartier (1996), que exploraram a importância das práticas de apropriação executadas pelos indivíduos em sua vida cotidiana, como forma de entender o processo de formação de sentido simbólico e político a partir dos meios de comunicação. Chartier enfatizou a história da leitura, enquanto Certeau estudou objetos da sociedade de consume. Em diferentes momentos da História, a relação entre produtores/emissores e consumidores/receptores indica não somente que os primeiros não possuem total controle sobre suas mensagens, mas também que os últimos não podem ser considerados senhores de seu destino, que elaboram sua interpretação da realidade isolados de suas ligações sociais. $\mathrm{O}$ trabalho desses historiadores ajuda a pensar de forma problematizada as redes e os circuitos de comunicação a partir de seus contextos históricos e de seus agentes específicos, e para além de teorias da comunicação que se pretendem a-históricas. Embora Marshall McLuhan tenha afirmado que "o meio é a mensagem" (1964), Certeau tem observado que os indivíduos processam a informação que recebem de formas variadas contestando-a, endossando-a, distorcendo-a. assim, é crucial para uma abordagem cultural sobre juventude evangélica e comunicação considerar essa relação entre produtores e consumidores, considerando tanto a produção e o consumo como processos criativos e exercícios de poder. atualmente, a internet oferece a oportunidade de estudar as relações que as pessoas - em especial as pessoas jovens - estabelecem com suas tradições e adesões religiosas assim como com outros grupos religiosos, ajudando tanto a misturar quanto a afirmar suas identidades religiosas.

A fim de compreender as mudanças e as novas configurações do engajamento juvenil na história evangélica, apresentarei uma breve consideração sobre cristianismo e 
juventude desde os anos 1960. Assim como em outras partes do mundo ocidental, a geração dos anos 1960 no Brasil estabeleceu um paradigma de atitudes, comportamentos e pensamentos que produziu uma ruptura no cenário sócio-cultural em termos de papéis de gênero, engajamento político e filiação religiosa, dentre outros aspectos. Em seguida discutirei as relações entre juventude evangélica e mídia de 2000 a 2010 em quatro sessões: primeiro, a ascensão de novas igrejas e de novas estratégias direcionadas para a juventude cristã no Brasil (católicos incluídos), dentre eles o uso da música, de eventos e festas, e da internet. Concluirei com uma reflexão sobre as possibilidades de aplicação das categorias teóricas de Michel de Certeau de "táticas" e "estratégias" para analisar esses casos.

\section{Juventude e Cristianismo no Brasil - Panorama Geral (1960-2010)}

Nos anos 1960, o Brasil era conhecido como um país jovem devido aos altos índices de natalidade e decrescentes taxas de mortalidade; a juventude brasileira era um retrato multifacetado de problemas e potenciais da sociedade brasileira: dependendo das condições sócio-econômicas em que os jovens foram criados, poderiam estar sujeitos à pobreza, abandono, drogas, criminalidade, prostituição. O problema dos menores abandonados tem sido parte de políticas públicas desde a virada do século XX, e mesmo no início do século XXI, milhares de adolescentes ainda encontram-se em situações de risco (FREITAS, 1997).

A violência doméstica contra jovens e mulheres ainda é um problema sério em meio ao cenário de crescimento econômico dos últimos dez anos. Desigualdades de oportunidade de trabalho e de salários referentes a gênero e raça ainda vitimizam mulheres negras. Os índices de gravidez na adolescência ainda continuem preocupantes, embora esteja em declínio (chegou a representar $25 \%$ das gravidezes no início dos anos 2000).

Neste breve cenário e incompleto panorama atual, que omite variações regionais, vale ressaltar que o Brasil é um país em processo de progressivo envelhecimento, ao mesmo tempo em que sua juventude tem atuado como agente de transformação social nas favelas, nas periferias, nas igrejas, nos lares e em demais espaços públicos e privados. 
A juventude, compreendendo de crianças a jovens adultos, tem sido reconhecida como uma categoria social e cultural legítima desde o início do século XX, no contexto de projetos de modernização conduzidos pela República Velha (1889-1930), no primeiro governo de Getúlio Vargas (1930-1945). Recentemente, o recorte demográfico concernente à juventude abrange pessoas de 15 a 24 anos, mas não é incomum encontrar estudos que considerem jovens de 15 a 29 anos.

Na primeira metade do século XX, a juventude era considerada a detentora do futuro da nação rumo ao desenvolvimento econômico, a fim de superar o atraso em relação às nações mais desenvolvidas da Europa. Políticas públicas tais como a universalização do ensino básico para crianças pobres e o melhoramento do ensino superior para s ricos, juntamente com projetos de confinamento de jovens considerados problemáticos ou delinquentes estavam no cerne da valorização da juventude como força de trabalho no Brasil.

Ao mesmo tempo, parte da juventude engajou-se em atividades políticas: em 1934 ocorreu o primeiro congresso da Juventude Estudantil-Operária, em 1937 a União Nacional Estudantil foi criada como oposição a Getúlio Vargas. De 1950 a 1970, a UNE e outros movimentos organizados juvenis lutaram pela democratização da educação. Tratava-se de um novo cenário para a juventude no Brasil, considerando que no século anterior havia uma valorização maior dos mais velhos em termos políticos e sociais, conforme Sobrados e Mocambos, de Gilberto Freyre (1936).

A juventude também foi o alvo principal da Igreja Católica após a proclamação da República. Antes disso, a Igreja já tinha investido na educação privada a fim de enfrentar o crescimento dos protestantes no Brasil, que iniciaram trabalho missionário e educacional desde meados do século XIX. Com a separação entre Igreja e Estado, a Igreja Católica procurou manter os canais de influência cultural e política, ganhando o privilégio de oferecer ensino religioso em escolas públicas no governo de Vargas. Desde os anos 1930 por meio da iniciativa de D. Sebastião Leme, muitos jovens católicos envolveram-se na Ação Católica por meio da Juventude Universitária Católica (JUC), a Juventude Agrária Católica (JAC), Juventude Estudantil Católica (JEC), a Juventude Operária Católica (JOC), e Juventude Independente Católica (JIC). Em seguida, nos anos 1960, membros da JUC compuseram a Ação Popular, distanciada da Igreja Católica, a fim de lutar contra a ditadura militar. 
Outra instância social que almejou a juventude no século $\mathrm{XX}$ foi a publicidade e a ainda incipiente sociedade de consumo. A juventude como virtude social foi proclamada nos anúncios de bens de consumo, sendo considerada como sinônimo de boa saúde, esporte, e melhoramento do corpo, preferencialmente nas praias da capital Rio de Janeiro (Maluf \& Mott, 1998). O ritmo cada vez mais acelerado das cidades em crescimento foi associado às silhuetas elegantes e fortes de jovens homens e mulheres nas páginas de novas revistas e jornais.

Ainda assim, para a maioria dos jovens na primeira metade do século XX, a adolescência era um período de intenso trabalho e estudo, sendo que o tempo de fruição foi estendido para a maior parte da juventude somente ao longo da segunda metade do século XX. A abordagem pedagógica para crianças e adolescentes era severa, na qual pais e professores eram considerados os detentores de todo o conhecimento, a quem os jovens deveriam prestar obediência absoluta, a fim de formar cidadãos patriotas em um contexto político autoritário. Essa era a tendência para a educação secular e religiosa, católica ou protestante, e nesse contexto, os protestantes produziram material que servia a essa abordagem, a fim de alcançar inserção social e legitimação cultural (BELLOTTI, 2010).

Isso mudou consideravelmente nas últimas três décadas, quando a juventude passou a ser considerada um mercado consumidor legítimo e independente. Além disso, novas abordagens pedagógicas foram introduzidas em escolas públicas e privadas a fim de transformar os estudantes em agentes do próprio aprendizado, sendo notável a imbricação entre educação e entretenimento em produtos voltados para essa faixa etária. Essas tendências foram abarcadas pela mídia religiosa produzida no Brasil desde os anos 1980, primeiramente por evangélicos e em seguida por católicos. Mais do que cidadãos patriotas, a mídia cristã juvenil almeja a formação de cidadãos-consumidorescrentes engajados e ecologicamente conscientes (IDEM, 2010).

Em termos políticos, nos anos 1960 parte da juventude brasileira esteve envolvida na contestação política do regime militar, incluindo grupos cristãos inspirados pela Teologia da Libertação e pelo movimento ecumênico protestante. Enquanto isso, nos anos 1970 houve tanto um aprofundamento do engajamento católico e protestante ecumênico, quanto uma diversificação dos canais de expressão e atuação juvenis nos meios protestantes, com a chegada de diversas organizações paraeclesiásticas. A 
comunicóloga Magali Cunha aponta esse período como de formação da cultura gospel, caracterizada pelo uso de música contemporânea dentro e fora dos templos, que fomentou a indústria fonográfica evangélica a partir dos anos 1980 e 1990 (CUNHA, 2007).

Além da cultura gospel, a partir dos anos 1980 e 1990 há um aumento no mercado de bens evangélicos direcionados para vida cristã, questões familiares, casamento e criação de filhos. Isso levou a uma padronização dos produtos oferecidos para uma crescente audiência de evangélicos (BELLOTTI, 2010). Nos anos 1990 e 2000 esse mercado evangélico consolidou-se juntamente com o aumento do percentual de evangélicos no Brasil - de 2,61\% da população no Censo de 1940, para 6,55\% em $1980,9,59 \%$ em $1990,16,22 \%$ in 2000 , e $22,2 \%$ em 2010, de acordo com o Censo religioso ${ }^{2}$.

O aumento do percentual de protestantes no Brasil também seguiu-se ao decréscimo no percentual de católicos ${ }^{3}$. Como a liderança católica considerou esse fenômeno o resultado de um esforço das "seitas" protestantes em atrair seus fiéis, um contra-ataque católico foi elaborado durante os anos 1980 e especialmente ao longo dos anos 1990 com o objetivo de manter a membresia católica, atrair filhos e filhas pródigos, e trazer novos membros para os templos. Uma atenção especial foi dada para aqueles que eram visto como suscetíveis de abandonar a religião para abraçar o "mundo" - a juventude. O mesmo tipo de atenção também foi dispensado aos jovens dentro de diversas igrejas evangélicas.

Em termos religiosos, parte da geração dos anos 1960 e 1970 foi responsável por uma ruptura geracional que não somente desassociou a identidade católica como parte da identidade brasileira, mas também introduziu outros elementos religiosos na formação religiosa brasileira, conferindo uma religiosidade mais personalizada e afastada da autoridade institucional (NOVAES, 2006).

$\mathrm{Na}$ década de 2000 a 2010, notícias sobre determinados movimentos e igrejas evangélicos demonstraram o engajamento da juventude na evangelização de seus pares

\footnotetext{
${ }^{2} \mathrm{Cf}$.

http://www.ibge.gov.br/home/estatistica/populacao/censo2010/caracteristicas_religiao_deficiencia/default _caracteristicas_religiao_deficiencia.shtm. Acesso em 16 de julho de 2012.

${ }^{3}$ De $95,01 \%$ no Censo de 1940 para $89,19 \%$ em 1980, 83,63\% em 1990, 73,90\% em 2000, e 64, $6 \%$ em 2010, de acordo com o Censo religioso de 2010 do IBGE. (Cf. Quadro comparativo: http://noticias.uol.com.br/cotidiano/ultimas-noticias/2012/06/29/populacao-evangelica-passa-de-154para-222-em-10-anos-e-atinge-423-milhoes-em-2010.htm. Acesso em 16 de julho de 2012).
} 
em concertos de rock, Marchas para Jesus, igrejas para quase todo tipo de tribo urbana. Do lado católico, os anos 1990 foram o período de ascensão dos padres cantores multimidiáticos, e do investimento maciço em canais de televisão e de rádio mais ligados à Renovação Carismática Católica (CARRANZA, 2000).

Os anos 1990 e 2000 também foram marcados pela popularização da internet e de uma ampla parafernália tecnológica que equipou a juventude cristã para se tornar produtora de sua própria mídia, produzindo blogs, websites, canais de bate-papo em uma velocidade muito maior do que qualquer ação institucional das igrejas. Por meio dessas ferramentas, essa juventude interage entre si, elabora e divulga eventos, discute tópicos bíblicos e comportamentais, remodela e refaz as fronteiras de sua fé.

O comunicólogo Henry Jenkins (2008) contestou que a definição de convergência da comunicação estivesse calcada na tecnologia de informação oferecida pela comunicação mediada pelo computador. Para ele, a convergência repousa sobre a disposição de indivíduos em produzir e circular a informação por meio de um processo coletivo de consumo. Tal realidade é visível no número de celebrações, manifestações, eventos, encontros promovidos pela juventude evangélica com a ajuda da internet. Nesse sentido, as antigas barreiras culturais são refeitas entre as tradições religiosas, as diferenças denominacionais e os estilos juvenis - estes geralmente considerados "mundanos" pelos padrões culturais evangélicos tradicionais. Tais mudanças no campo evangélico não implicam que estes aspectos supostamente "mundanos" tenham sido aceitos por todos os evangélicos - mesmo entre os mais jovens, alguns elementos são alvo de negociação: posso ouvir rock and roll depois da minha conversão? Devo apagar minhas tatuagens depois de encontrar Jesus? - são algumas das questões que perturbam parte dessa nova juventude evangélica.

Contudo, nota-se um remodelamento mútuo de práticas religiosas à luz de três aspectos: novas demandas juvenis em relação à religião, novas respostas oferecidas por instituições religiosas e de uma autonomia religiosa individual mais ampla experimentada no Brasil desde os anos 1950 e 1960. A mídia exerce um papel crucial nesse remodelamento, seja por meio da ação de instituições, seja pela iniciativa de indivíduos. 


\section{A Juventude Evangélica e a Mídia nos anos 2000 a 2010}

\section{2.a) Novas Demandas, Novas Igrejas, Novas Estratégias}

Um caso muito interessante igrejas de diáspora de jovens evangélicos de igrejas tradicionais é a Comunidade Golgota, fundada na cidade de Curitiba-PR em 2001. A pequena igreja foi fundada pelo pastor Pipe, um jovem presbiteriano fã de heavy metal, detentor de um diploma de Teologia e de uma grande insatisfação com sua igreja por conta da ausência de espaço para jovens como ele.

Diferente da grande tendência predominante no campo evangélico atual, essa nova comunidade cristã não é pentecostal, mas sim parte de outra crescente tendência detectada no último censo - o crescimento de congregações pequenas e independentes criada por dissidentes de grande denominações.semelhante a outras novas igrejas, a Golgota mantém diversos canais de comunicação, centralizados em seu website, que possui: blog, link para Twitter, Facebook, Orkut, "metalcast" (com arquivos de áudio contendo comentários e estudos bíblicos feitos pelo Pastor Pipe), um link para o Motorclub da igreja, para as bandas de seus membros, entre outras atividades. De acordo com texto publicado no website, "a estratégia [da igreja] era ter um local que abraçasse as tribos e suas expressões culturais. Diante disso, tínhamos um culto com uma proposta voltada para os rockeiros em geral. Louvor com muito heavy metal, punk rock, hardcore, etc." ${ }^{4}$.

Um dos desafios para futuros pesquisadores é saber como essas instituições lidarão com o envelhecimento de sua membresia - continuarão a se direcionar para a juventude, ou acomodarão outras gerações? Recentemente, a Bola de Neve Church tem demonstrado a frequência de aderentes mais velhos, muitas vezes parentes e pais de jovens convertidos, enquanto que membros jovens adultos têm se casado e trazido seus filhos para os cultos.

A Bola de Neve Church é uma igreja pentecostal nova que se dirige para uma membresia juvenil. Surgiu em 1998 e é conhecida como a "igreja dos surfistas" por conta de sua origem em um galpão de uma loja de roupas de surfe (Haiwaian Dreams H.D.). Fundada pelo apóstolo Rina em São Paulo-SP, o nome Bola de Neve faz referência à idéia que Rina teve para seu ministério - uma pequena iniciativa que se

\footnotetext{
${ }^{4}$ Cf. http://golgotacuritiba.blogspot.com/p/historia.html. Acessado em 29 de novembro de 2011.
} 
tornaria enorme, crescendo como uma bola de neve. Uma das marcas registradas da igreja é uma prancha de surfe longboard no lugar do púlpito, além da presença de música contemporânea nos cultos, comum a várias outras igrejas pentecostais mais recentemente. Trata-se de uma igreja moderna, que utiliza muitos recursos de comunicação, dirigida por pessoas jovens e que atrai muitos jovens sem exigir qualquer mudança na forma de se vestir ou de falar. Porém, os líderes pregam condutas morais e sexuais tradicionais, como relacionamento monogâmico, sexo após o casamento, nada drogas, nem álcool, nem fornicação ${ }^{5}$. Um dos de seus mais famosos convertidos é o roqueiro Rodolfo Abrantes, conhecido pela banda de forró-core Raimundos, cujas letras eram repletas de referências a drogas e a sexo. Desde o início dos anos 2000 ele tem conduzido sua carreira musical com letras de louvor e adoração sem deixar o rock de lado.

\section{2.b) Eventos para a Jovem Geração}

É plenamente conhecido que a música faz parte da prática e da devoção dos protestantes desde a Reforma. No Brasil, a música em forma de hinário sempre foi alvo de grande atenção para os evangélicos, pois ela se tornou uma característica distintiva da identidade protestante dentro de um país católico. O hinário tradicional prevaleceu nas igrejas de meados do século XIX até os anos 1950, quando algumas mudanças ocorreram, começando pelos missionários americanos da Igreja do Evangelho Quadrangular, que tocavam simples canções na guitarra elétrica, e chegando até os dias atuais com as grandes estrelas da música gospel brasileira dos anos 1990 e 2000. Jovens músicos introduziram instrumentos elétricos e ritmos populares para louvar dentro e fora das igrejas. E até mesmo em missas católicas.

Esse é o caso da Cristoteca (BELLOTTI, 2011b), uma balada católica criada em meados dos anos 2000 em São Paulo com DJ de música eletrônica, com missa comunhão e louvor em um ambiente livre de drogas e álcool. Ao analisar como este evento estava sendo avaliado pelos seus participantes em discussões de fóruns do Orkut em 2010, deparei-me com uma intrigante questão lançada pelo moderador da comunidade "Cristoteca Agenda SP": "qual banda ou artista gospel você gostaria de ver

\footnotetext{
${ }^{5}$ Cf. Site oficial da Bola de Neve: http://www.boladeneve.com/. Acessado em 17 de dezembro de 2011.
} 
na Cristoteca?". A quantidade de respostas dadas por jovens católicos sugerindo bandas e artistas evangélicos para o momento do louvor, juntamente com depoimentos de pessoas que já tinham prestigiado esses artistas neste contexto, mostra que o consumo cristão juvenil no Brasil tem contribuído para misturar as fronteiras denominacionais, mesmo em eventos com controle institucional como a Cristoteca (ver figuras 1 e 2).

Certamente, houve usuários participantes da discussão que se opuseram ferozmente à presença de evangélicos na missa, relembrando os conflitos do período da Reforma. Alguns destes usuários citavam documentos do papa Bento XVI retirados do site do Vaticano. Contudo, a maior parte das respostas manifestou interesse em ver artistas gospel bem conhecidos, tais como a banda de rock Oficina G3 e as cantoras Aline Barros e Ludmila Ferber.
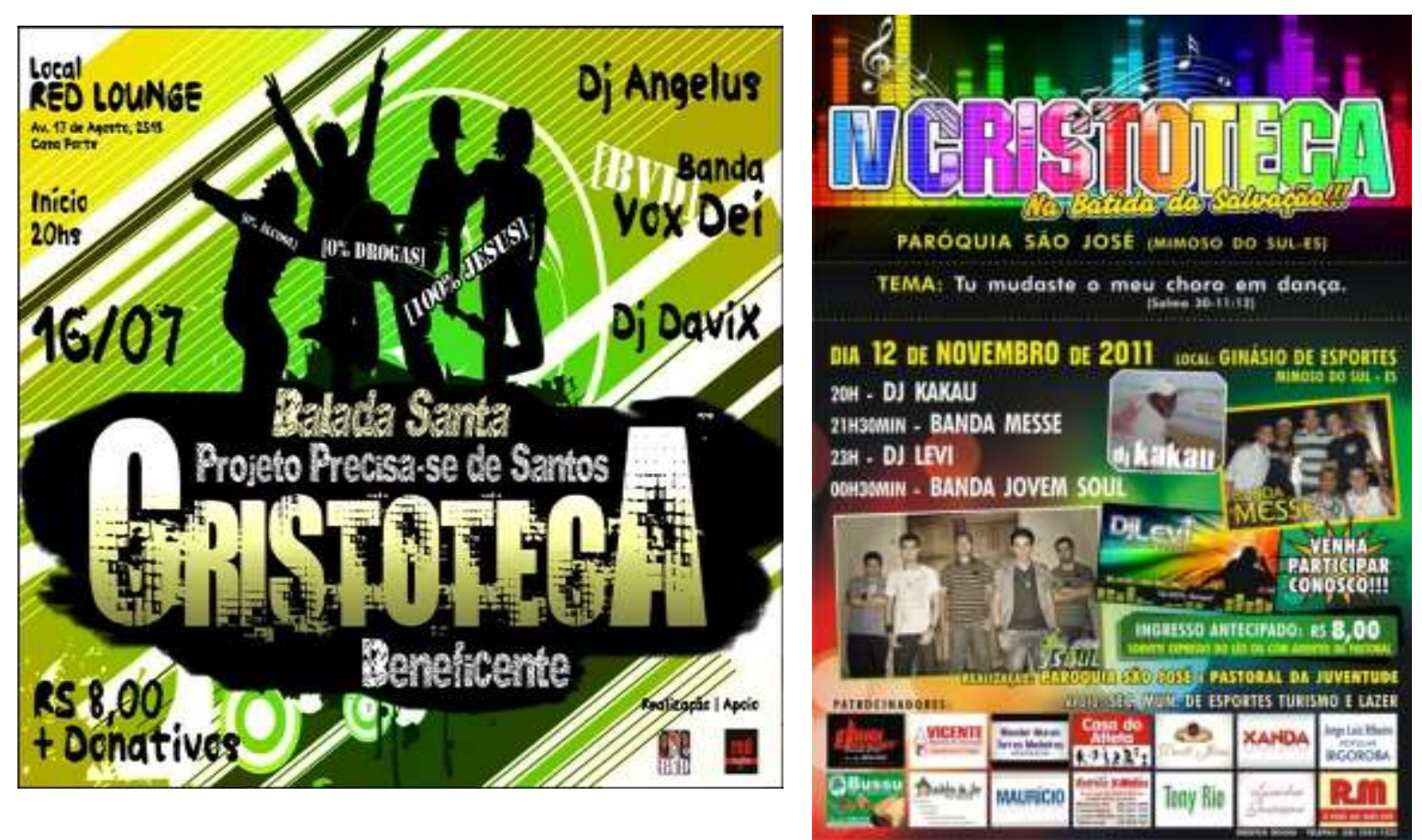

Figuras 1 e 2) Divulgações virtuais (flyers virtuais) de duas Cristotecas ocorridas em 2010 e 2011 a primeira, à esquerda, em Recife-PE, e outra, à direita, em Mimoso do Sul-ES (fontes: http://filhosdamisericordia.wordpress.com/2010/07/08/cristoteca-beneficente-bvd \% E2\% 80\% 8F/; http://mimosodosul.blogspot.com.br/2011/11/iv-cristoteca.html). É interessante notar uma breve discussão feita no site que divulgava o primeiro evento, sobre o caráter festivo da Cristoteca, que estaria negligenciando o caráter "crístico" de sacrifício, ao que um dos organizadores responde evocando Tiago $3.17^{6}$.

6 “11/07/2010 às 16:04 - PREZADOS (AS), Pela intenção beneficente do evento, parabenizo aos idealizadores e seus colaboradores. Outrossim, não se dá com o uso da palavra designativa do mesmo, qual seja "CRISTOTECA", uma vez que na vida de Jesus, "CRISTO" foi um momento "CRÍSTICO" indicativo de sofrimento cruel e dolooroso (sic) por uma causa grandiosa: Nossa Salvação. Associar tal 
É fato que a indústria fonográfica evangélica tem crescido nas últimas duas décadas, apesar do declínio da indústria fonográfica secular desde o final dos anos 1990, por conta da pirataria e do aumento da oferta de downloads gratuitos de músicas pela internet. Nos últimos anos o mercado secular tem contratado artistas gospel para recémcriados selos gospel. Ainda que exista pirataria no meio evangélico, existem altos índices de vendas de CDs e DVDs ${ }^{7}$. Além disso, outro fenômeno musical na cultura evangélica são as emissoras de rádio dedicadas à música gospel, dirigidas para audiências juvenis, emulando o formato de estações de rádio pop seculares. Juntamente com a música pop, outros ritmos tem sido usados por diversos artistas independentes, para além do heavy metal e do rock $^{8}$ : o funk carioca (frequentemente associado a um contexto sexual e/ou violento na sua forma secular), pagode, hip hop e rap (ver figuras $3,4,5$ e 6$)$.

Além da música evangélica, outra estratégia para se aproximar da juventude são os mais variados eventos promovidos por igrejas, organizações paraeclesiásticas e grupos independentes. Desde o seu início, em 1986, a Igreja Renascer em Cristo é

relevância á um evento cujo ( $\mathrm{sic}$ ) publicidade o aponta como festivo e de discontração (sic), não me parece coerente, quiçá respeitoso, sem detrimento das considerações niilistas, possíveis, apesar de já há alguns anos, ter conhecimento de termo. Que Deus os ilumine. Sandive Santana. Paróquia de São Tiago Apóstolo / Lins / RJ

Resposta - 02/08/2010 às 19:28 - Olá Sandive Santana, Apesar de não termos criado este termo que nomeia este tipo de evento, ele se encaixa perfeitamente. O nome dá luz à proposta: $\mathrm{O}$ "Disco" pelo "Cristo", ninguém vai lá para dançar somente, e sim para louvar ao Cristo, vão em busca dele. E sobre a dimensão crística, há um texto muito bom sobre, que diz: Ser "crístico" é ser gracioso. É ter palavras que abençoam. Que curam. Palavras que levantam as pessoas. Palavras encorajadoras. Palavras sábias. Aliás, Tiago coloca muito bem esta questão. "A sabedoria, porém, lá do alto é, primeiramente, pura; depois, pacífica, indulgente, tratável, plena de misericórdia e de bons frutos, imparcial, sem fingimento" (3.17). O "crístico" está sempre falando a verdade com amor. A sua visão das pessoas é a partir do ensino bíblico. A lente através da qual ele vê as pessoas é Jesus Cristo, a Palavra feita carne. O "crístico" está crucificado com Cristo e Cristo vive nele. "Fui crucificado com Cristo. Assim, já não sou eu quem vive, mas Cristo vive em mim. A vida que agora vivo no corpo, vivo-a pela fé no Filho de Deus, que me amou e se entregou por mim". (Gl 2.20 - NVI). Ser "crístico" significa falar palavras temperadas com sal que edificam as pessoas, contribui para melhorar a sua vida. Ele não guarda amargura no coração. Suas palavras são doces, agradáveis. Você tem prazer em conviver com o crente que um dia morreu com Cristo para servi-1O e ao próximo. Ele não entra na roda dos críticos. Dos que querem prejudicar para se beneficiarem. A palavra do "crístico" é bom remédio para o coração. Somos chamados para vivermos a vida de Cristo com todas as nossas limitações. Paz e Bem pra vc. Unidos em ação e oração. Gildson (Banda Vox Dei), Recife-PE. Organização Projeto Precisa-se de Santos" (Cf.

http://filhosdamisericordia.wordpress.com/2010/07/08/cristoteca-beneficente-bvd\%E2\%80\%8F/). Acessado em 20 de julho de 2012.

${ }^{7}$ De acordo com a reportagem da Folha de São Paulo de 20 de novembro de 2011, os artistas evangélicos mais populares venderam cerca de 350 mil a um milhão de álbuns por ano, semelhante à marca de artistas seculares de alta vendagem. Cf. http://www1.folha.uol.com.br/ilustrada/1008562-em-crise-gravadorastradicionais-buscam-mercado-religioso.shtml. Acessado em 17 de dezembro de 2011.

${ }^{8}$ Para um estudo mais aprofundado sobre a música evangélica contemporânea, ver os trabalhos de Magali Cunha (2007) e Airton Jungblut (2010). 
conhecida por seu envolvimento com a juventude, incluindo a organização da edição brasileira da Marcha para Jesus, que congrega diversas igrejas evangélicas, em sua maioria pentecostais. Além disso, a Renascer registrou a marca "gospel", amplamente usada em seus programas de rádio, TV e comunicação em geral, e investe no ministério de louvor e adoração Renascer Praise, que realiza monumentais concertos, gravados em DVD.

A igreja também tem promovido desde 2006 os eventos de lutas Fight Night e Reborn Fight, organizado pelo Ministério Reborn Team, voltado para o público masculino jovem, que agrega lutadores de diversas modalidades (judô, caratê, jiu-jitsu, MMA, etc). Ainda que se encontrem informações sobre grupos de treino femininos, há uma predominância masculina. $\mathrm{O}$ evento surgiu de uma iniciativa da igreja de oferecer aulas de modalidades de luta para jovens carentes. A popularidade do MMA (Artes Marciais Mistas) nos últimos anos conferiu visibilidade aos torneios, da mesma forma que alguns lutadores famosos têm declarado sua fé evangélica, como Wanderlei Silva, Anderson Silva e Victor Belfort.

O slogan nos cartazes dos torneios é “A noite em que os guerreiros se reúnem para lutar", trazendo imagens de lutadores de diversas modalidades. A evocação do imaginário bíblico do guerreiro é significativa, pois procura dissociar o torneio e as modalidades esportivas da conotação violenta que possuem. A ênfase do discurso dos pastores responsáveis é na disciplina e na lealdade, ressaltando o esporte como um veículo de formação de caráter, cujos eventos têm o potencial de atrair jovens que não aceitariam um convite para um culto, mas não se negariam a assistir a lutas de artes marciais (ver figuras 6 e 7$)^{9}$.

Outro evento que tem ganho notoriedade é a Gospel Night, uma festa com DJ de música eletrônica, que tem sido imitada por grupos independentes com o mesmo nome, animando noites e até vigílias. A música eletrônica está presente também nas noites de luta da Renascer, ao mesmo tempo em que uma rápida busca na internet nos leva a diversos DJs autodenominados cristãos.

\footnotetext{
${ }^{9}$ Conforme reportagem do próprio veículo oficial da Renascer, o site iGospel: "Reborn Fight III: O ringue da Salvação". Disponível em: http://www.igospel.org.br/br/noticia.php?m=*9089B59CC0509C9229669EBBFC31A2A40D7527E2. Publicado em 22 de julho de 2011. Acessado em 19 de julho de 2012. Nota-se, porém, que este ministério específico não possui um site em funcionamento e há pouca informação escrita sobre os eventos, havendo muito mais vídeos disponíveis no You Tube com as lutas.
} 

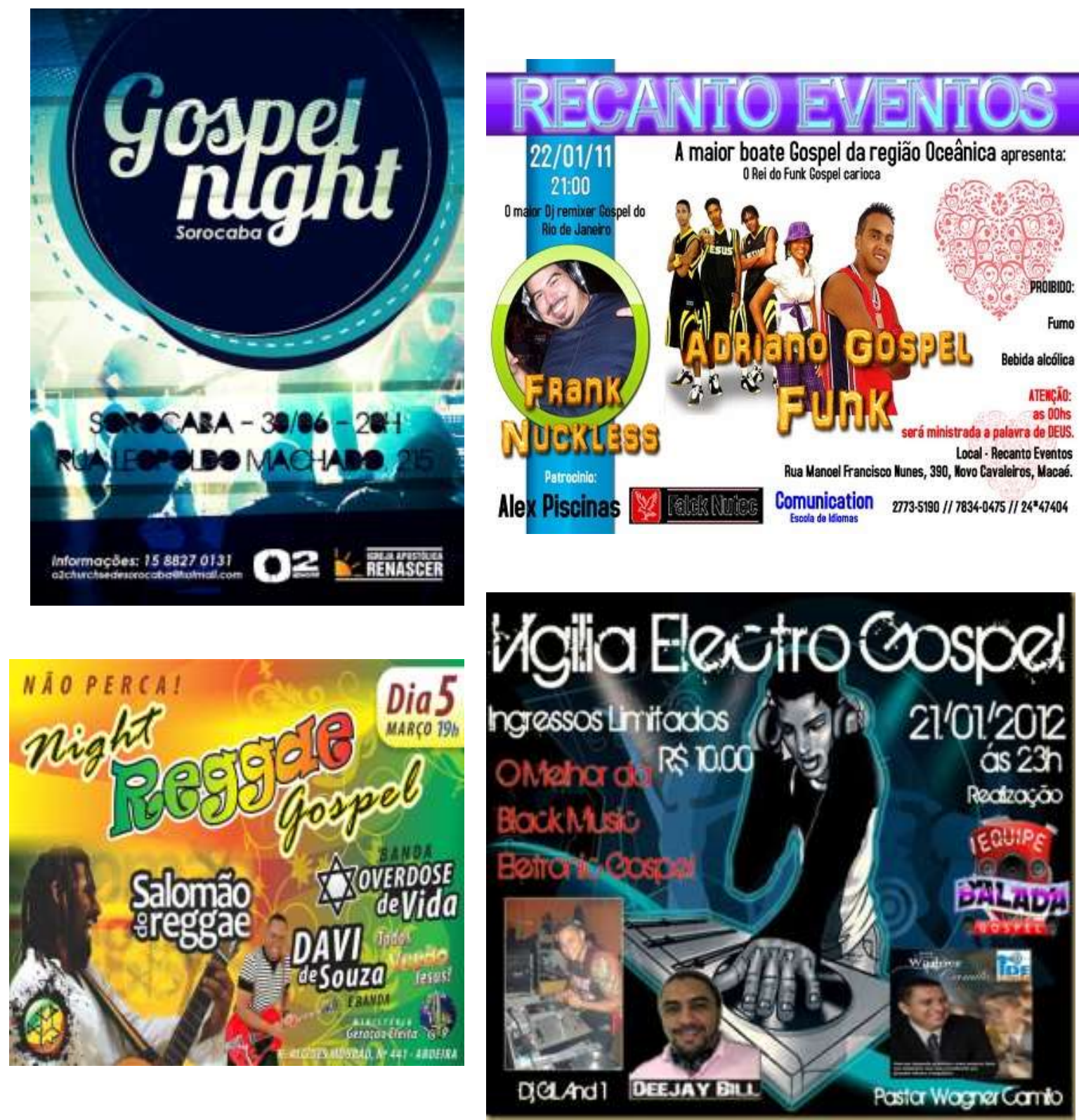

Figuras 3, 4, 5 e 6) Em sentido horário, figuras 3, 4, 5 e 6: Flyers respectivamente de Gospel Night promovida pela Igreja Renascer em Cristo de Sorocaba em junho de 2012; flyer de festa funk gospel promovida em Macaé-RJ, em janeiro de 2011 na "maior boate gospel da região oceânica"; flyer de show de Reggae - Night Reggae Gospel em Macaé, em 2011; E flyer de Vigília Electro Gospel promovida pela Equipe Balada Gospel, em 2012 em Guaianazes-SP (fontes: http://www.renascersorocaba.com.br/2012/06/30062012-sede-estadual-sorocaba-gospel.html; http://louvemacae.wordpress.com/2011/01/13/noite-gospel-recanto-eventos-gospel/; http://www.deejaybill.com.br/2011/12/vigilia-eletro-gospel/). 


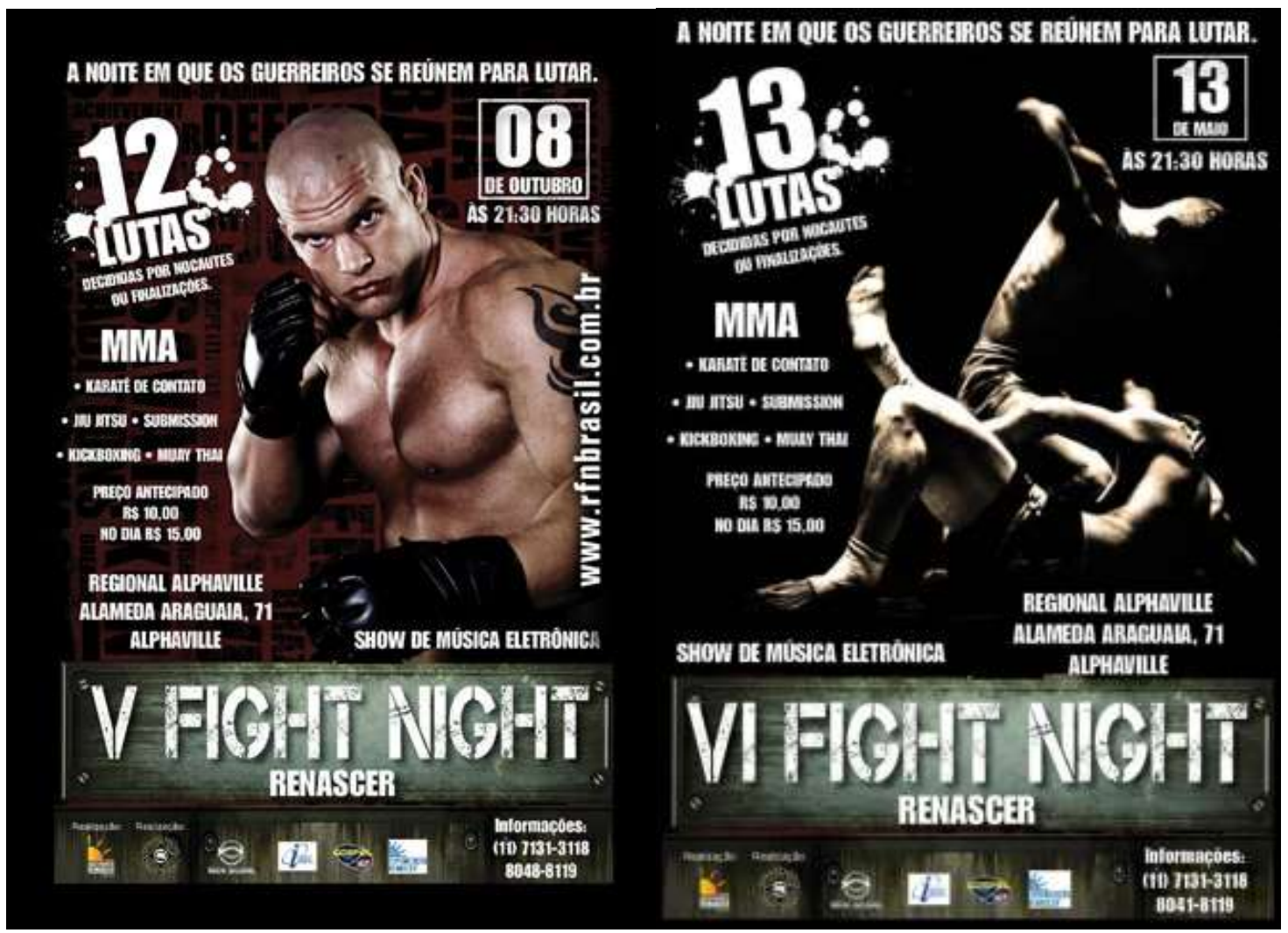

Figuras 7 e 8) Cartazes virtuais de dois torneios V e VI Fight Night - em 2010 e 2011, na Igreja Renascer em Cristo regional Alphaville, em São Paulo-SP (Fontes: http://www.guiame.com.br/noticias/gospel/mundo-cristao/lutadores-participam-do-v-fight-nightrenascer.html,

http://www.ig0spel.org.br/br/noticia.php?m=*68B87FF7F002D954DB1DA59DC8F0EDF98A930C6 2)

Por sua vez, a Bola de Neve Church também possui um ministério de esporte, a Bola Blitz, e promove campeonatos e demonstrações de skate e surfe, juntamente com concertos de rock e reggae. Também já promoveu tardes e noites de feijoada com pagode, acampamentos e retiros (estes, práticas mais comuns entre a juventude evangélica e católica), festas caipiras (há a prática independente de se fazer "Festas Juninas Gospel", ignorando o fato de as festas juninas serem ligadas ao catolicismo ver figuras 9, 10, 11 e 12).

Além da tradicional organização Atletas de Cristo, outras associações mais recentes têm surgido, como os Surfistas de Cristo e a Associação Cristã de Surf. Os Surfistas já chegaram a lançar uma bíblia em parceira com a SBB - Sociedade Bíblica do Brasil, em 2007 - “A Bíblia do Surfista”, uma bíblia "por e para” surfistas, segundo 
release da $\mathrm{SBB}^{10}$. Até a Renovação Católica Carismática promoveu evento para o público jovem na praia, intitulado "Jesus no Litoral", com música, demonstrações e adoração. É notável observar a existência dessas iniciativas que até não muito tempo atrás eram ignoradas pelo meio evangélico, por conta de sua rejeição ao aspecto físico da experiência cristã. Por outro lado, existem críticas vindas de evangélicos quanto ao caráter violento (esportes de contato) ou festivo demais de algumas destas iniciativas ao invés de atender ao chamado evangelístico, essas atividades são criticadas por blogueiros evangélicos por pregarem para o rebanho convertido.

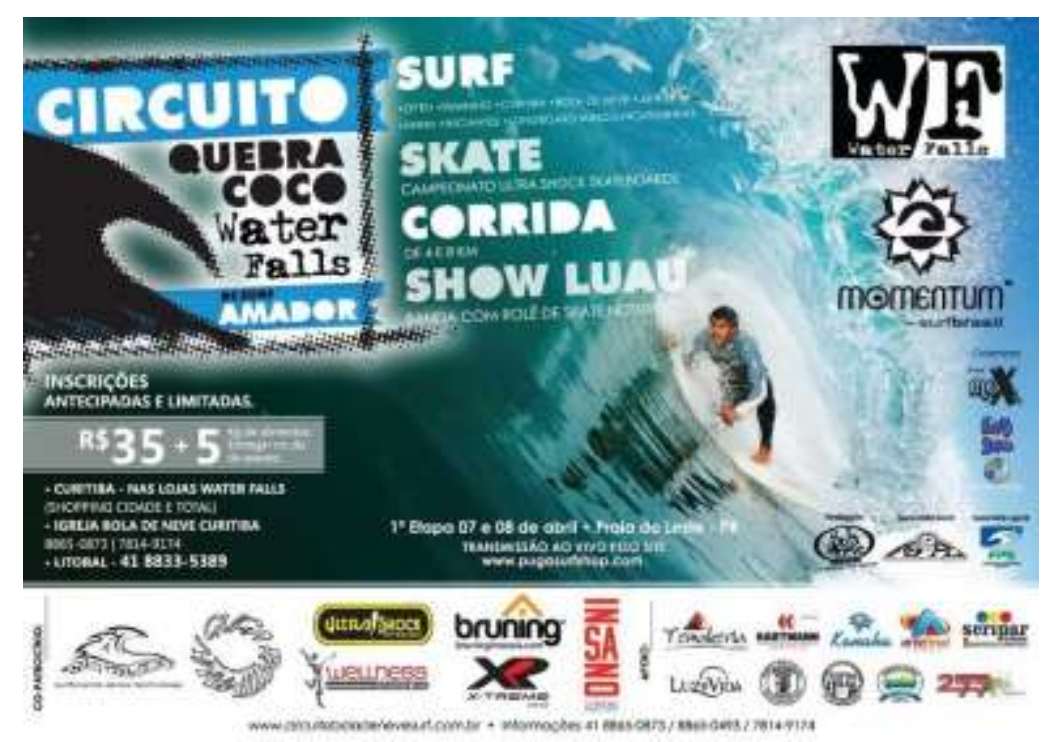

Figura 09 - flyer virtual do Circuito Quebra Coco Water Falls, patrocinada pela Bola de Neve na Praia do Leste-PR, em abril de 2012 (fonte: http://automotivefamily.blogspot.com.br/2012/04/aviso-importante-e-convite-para-1-etapa.html)

${ }^{10} \mathrm{Cf}$. http://www.sbb.com.br/detalhes.asp?idproduto=1116416. Acessado em 19 de julho de 2012. 


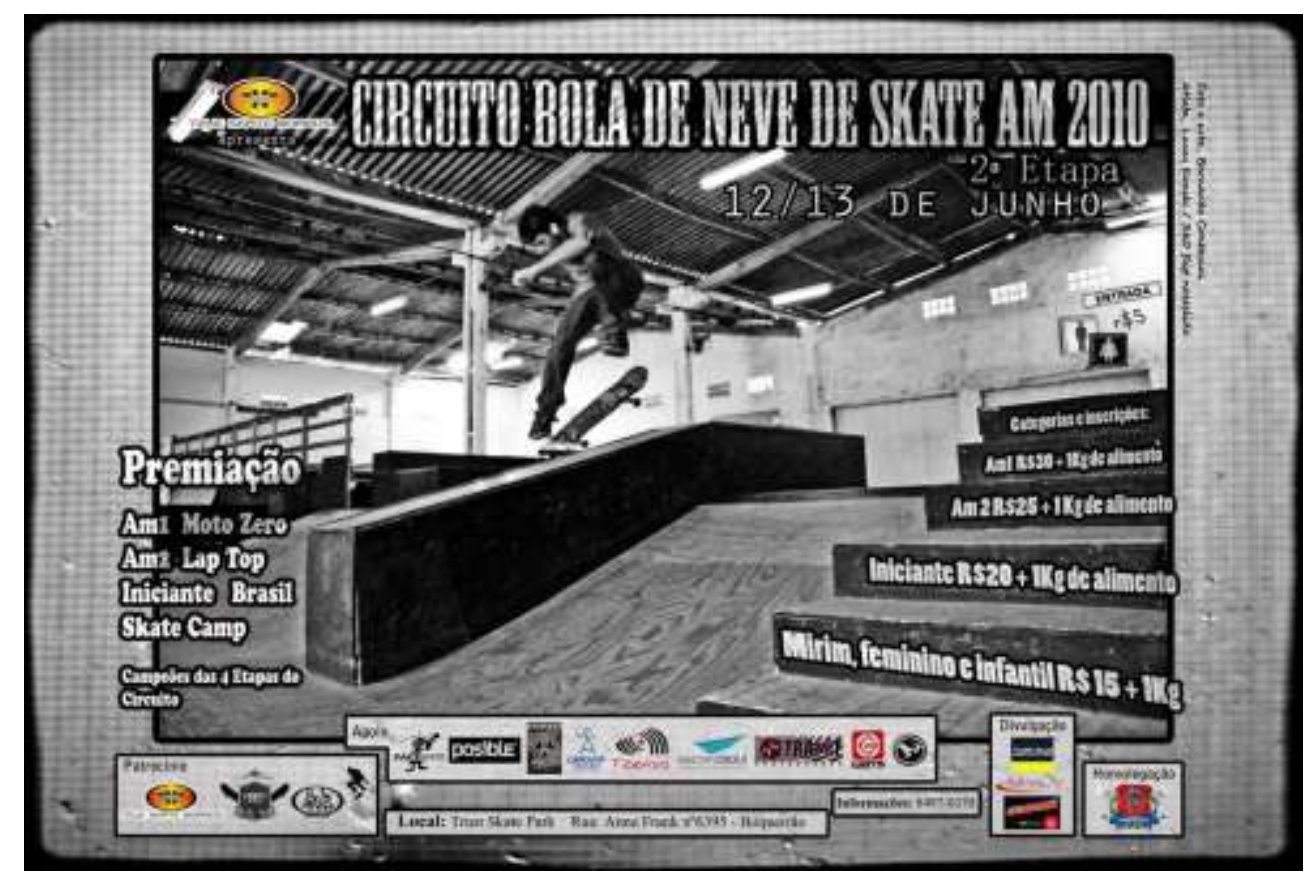

Figura 10 - Flyer de Circuito Bola de Neve de Skate Amador em 2010, em Curitiba-PR (Fonte: http://campeonatosdeskate.blogspot.com.br/2010/05/circuito-bola-de-neve-de-skate-am-2010.html).

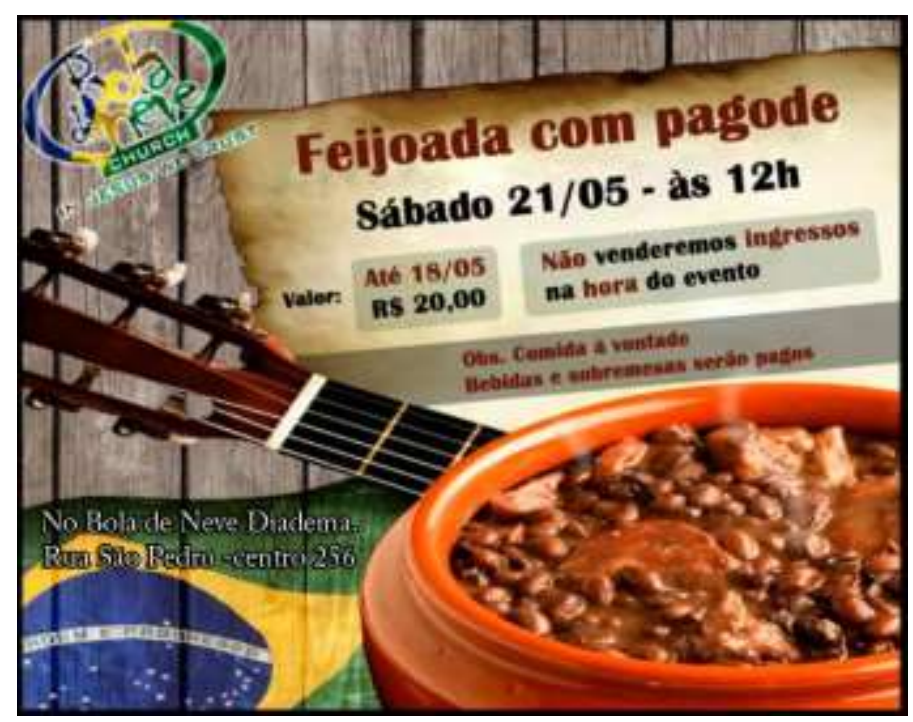

Figura 11 - Flyer da Feijoada com Pagode patrocinada pela Bola de Neve em Diadema, em maio de 2011 (fonte: http://blog.divulgasomgospel.com.br/eventos/feijoada-com-pagode-gospel-dia-21-demaio-as-12h-no-bola-de-neve-diadema/). 


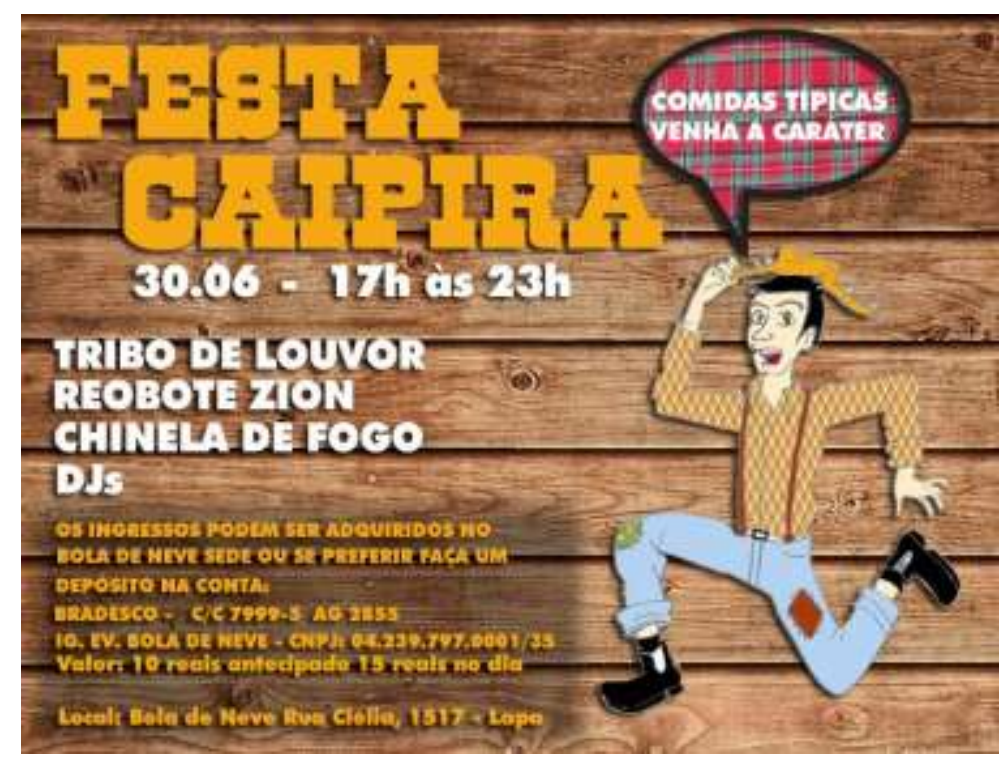

Figura 12 - Flyer da Festa Caipira da Bola de Neve da Lapa (São Paulo-SP) em 30 de junho de 2012 (fonte: http://garimpodasmeninas.blogspot.com.br/2012/07/dica-de-festa-junina-bola-de-nevesbc.html).

\section{2.c) Internet - Blogando por Cristo}

A internet é um veículo bastante utilizado para a mobilização e a expressão da juventude evangélica, como se pode observar em uma busca por blogs, websites e redes sociais. Os evangélicos foram o primeiro grupo religioso a usar a internet no início de sua implantação no Brasil, no final dos anos 1990, sejam pelo uso de salas de bate-papo, seja demonstrando sua fé em páginas pessoais, seja por páginas institucionais (JUNGBLUT, 2000).

Em fóruns do Orkut e do Facebook, jovens evangélicos repletos de dúvidas quanto à conduta mais apropriada como verdadeiros cristãos procuram respostas entre seus pares por meio do compartilahmento de experiências e conselhos. Portanto, a internet torna-se uma ferramenta de instrução religiosa, na qual o crente pode encontrar textos sagrados, reflexões teológicas e estudos bíblicos, aconselhamento e sociabilidade.

Além disso, a internet é também um meio de protesto contra certas práticas teológicas na cultura evangélica brasileira, tais como a Teologia da Prosperidade. Alguns blogueiros evangélicos utilizam ironia e paródia para criticar líderes 
neopentecostais proeminentes, como Estevam e Sonia Hernandes, fundadores da Renascer em Cristo, Edir Macedo, fundador da Igreja Universal do Reino de Deus, e o Silas Malafaia, pastor assembleiano que tem se destacado não somente pela sua duradoura ministério de comunicação, mas também por seu mais recente engajamento político contra as causas gays e pró-aborto.

Alguns destes blogueiros fazem protestos silenciosos dentro de eventos como a Marcha para Jesus e a Expo Cristã SP. Esses jovens adultos comparecem usando camisetas pretas e banners com os dizeres: "O \$how tem que acabar - De volta ao Evangelho Puro e Simples" (em referência ao livro de C.S. Lewis, "O Evangelho Puro e Simples"). Esse grupo filma os protestos, disponibilizando-os em seus blogs. Dois blogueiros, o casal Vera e Paulo Siqueira, que mantém os blogs "Uma estrangeira no mundo" e "As pedras clamam", respectivamente, foram convidados a abrir uma nova igreja a fim de reunir os seus seguidores da internet, em sua maioria cristãos insatisfeitos com a tendência supostamente mercantilizante no campo evangélico. Por exemplo, no dia 31 de outubro de 2011, um grupo de blogueiros afixou as 95 teses de Martinho Lutero na frente de igrejas neopentecostais da cidade de São Paulo. Em um texto intitulado "A verdade que transforma", de 16 de outubro de 2011, no protesto contra a Marcha para Jesus nas cidades de Belo Horizonte-MG e São Bernardo do Campo-SP, Paulo Siqueira escreveu:

“Que Deus temos anunciado? Um deus desprovido de misericórdia,
de solidariedade, que não produz fé pois vem separado da vivência
cotidiana, e desvinculado da história. Um deus longe da Bíblia, que
não se relaciona com o ser humano. Um deus que, para muitos, não
sabe conviver com as fraquezas e as debilidades de ser-humano. Nós,
do Movimento pela Ética, após muitas marchas chegamos a uma
conclusão: se faz necessário um grande milagre para mudar a mente e
o coração de muitos, pois o que temos aí afirmamos e repetimos, são
propósitos humanos. Cristo é simplesmente a moeda de troca. Com
isso, partimos para novos caminhos. Muitos, a partir de agora,
encontrarão pelo caminho os membros deste movimento, pois para
uma mudança verdadeira no contexto evangélico brasileiro, se faz
necessário "invadir culturalmente" este país com uma mensagem viva,
e que interaja com o cotidiano de cada um." 11

Em 2007 a União dos Blogueiros Evangélicos foi criada por dois jovens adultos, congregando cerca de 20 mil afiliados (contagem de agosto de 2014). Contudo, uma das

${ }^{11}$ Cf. http://pedrasclamam.wordpress.com/. Acessado em 4 de dezembro de 2011. 
reclamações de seus fundadores é a enorme quantidade de blogs com conteúdo evangelístico mínimo e, consequentemente, baixo impacto na blogosfera. De fato, a maioria dos blogs consultados ofereceu um conteúdo muito parco.

Assim como os estudos pioneiros de Airton Jungblut (2000; 2010) e Alexandre Brasil Fonseca (1997) demonstraram no final dos anos 1990 e início dos 2000, os evangélicos foram o primeiro grupo religioso a usar as várias ferramentas da internet, seja individualmente, seja institucionalmente. Sem dúvida, a internet tem influenciado no contrabalanço ao peso da autoridade institucional no campo evangélico, visto que ela oferece canais de expressão distantes do controle institucional.

Dado o potencial múltiplo da internet, a Igreja Adventista do Sétimo Dia tem investido no evangelismo pela rede. Apesar de recusar para si a caracterização de "evangélica", a IASD está inserida no campo evangélico brasileiro, contando com um dos ministérios de comunicação mais antigos do país. Recentemente, a igreja lançou pelo portal do seu Ministério Jovem uma campanha de instrução para evangelismo na internet, fornecendo ferramentas e estratégias para os usuários adventistas construírem suas próprias páginas e otimizarem a comunicação em favor da evangelização ${ }^{12}$. Aliás, a IASD é uma igreja que tem se preocupado em oferecer diferentes espaços de atuação para seus jovens, unindo evangelização e vários tipos de ação social.

\section{Conclusão: A juventude evangélica sob uma perspectiva de produção e consumo culturais}

Uma das conclusões deste estudo em andamento é que não se deve pressupor que a juventude evangélica brasileira possui qualquer natureza conservadora ou transformadora. A perspectiva histórica implica abrir para a diversidade de atitudes, ações e pensamentos. Assim como há jovens marchando para Jesus, experimentando um sentimento de pertença a uma grande nação, existem outros jovens que criticam essa e outras iniciativas. Certeau já alertava para a heterogeneidade das práticas culturais, a serem analisadas pelo historiador sem hierarquizações. Consumo, missão e devoção são instâncias imbricadas no amplo espectro de evangélicos em nosso país.

${ }^{12}$ Cf. http://evangelismoweb.com/pt/. Acessado em 19 de julho de 2012. 
Analisei somente uma pequena fração das diferentes práticas de jovens evangélicos nos últimos dez anos. Há uma visível diferença em relação ao panorama traçado no início do texto: há uma autonomia maior dos indivíduos em geral, e dos jovens em particular, quanto à condução de sua vida religiosa; uma união maior desta juventude em torno de comunidades de interesses específicos, sejam guiados por faixa etária, sejam por afinidades musicais, localização regional, atividades em grupo de evangelização, prática de esporte, ações sociais, dentre outras. Magali Cunha (2007) apontou a predominância da tríade consumo-entretenimento-música na cultura gospel, que possui grande apelo entre os jovens evangélicos. $O$ fato de a cultura evangélica atual estar permeada pela cultura de entretenimento, celebração e consumo, sujeita a hibridismos com outras práticas até então consideradas mundanas - feijoada com pagode gospel, lutas de contato com oração, heavy metal cristão -, não pode ser analisada como uma banalização ou desvirtuamento do cristianismo - não aos olhos das ciências sociais. A pergunta que fazemos é: o que essas práticas representam para seus agentes? O que elas promovem? Quem as promove? Por quê?

Utilizei muito neste texto o termo "estratégia" para me referir as essas práticas desenvolvidas tanto por igrejas quanto por indivíduos e grupos independentes para se aproximar do público jovem. Para Michel de Certeau, estratégia é a ação planejada pelos produtores da cultura para regular as atividades de seus receptores:

“As estratégias são portanto ações que, graças ao postulado de um lugar de poder (a propriedade de um próprio), elaboram lugares teóricos (sistemas e discursos totalizantes), capazes de articular um conjunto de lugares físicos onde as forças se distribuem. Elas combinam esses três tipos de lugar e visam dominá-los uns pelos outro. Privilegiam portanto as relações espaciais. Ao menos procuram elas reduzir a esse tipo as relações temporais pela atribuição analítica de um lugar próprio a cada elemento particular e pela organização combinatória dos movimentos específicos a unidades ou a conjuntos de unidades. O modelo para isso foi antes o militar que o "científico". As táticas são procedimentos que valem pela pertinência que dão ao tempo - às circunstâncias que o instante preciso de uma intervenção transforma em situação favorável (...)" (CERTEAU, 1998, p.102). 
Certeau ilustrou o conceito de estratégia/tática com o ato de comprar no supermercado - a estratégia do supermercado está inscrita em seu espaço, delimitando a entrada e a saída dos consumidores, situando as mercadorias supostamente supérfluas nos primeiros corredores, e as essenciais nas últimas. Contudo, os compradores sempre fazem suas escolhas baseadas em muitas variáveis: renda, gosto, disponibilidade de produtos, curiosidade, etc. No supermercado, o consumidor comum faz sua "intervenção" que transforma o "campo inimigo" em uma situação que lhe seja favorável.

Poderíamos aplicar essas mesmas categorias para analisar as práticas religiosas discorridas ao longo deste capítulo? Um dos problemas desta conceituação é que ela aparenta ser flexível demais - da cultura de consumo à pedagogia, da invenção do cotidiano às práticas religiosas. Porém, é essa flexibilidade destes conceitos, concebidos para explicar movimentações da sociedade contemporânea, que nos permite refletir sobre a fluidez das práticas cotidianas e o cabo-de-guerra de forças assimétricas que constituem a construção de práticas, idéias, identidade e sentimentos religiosos.

Podemos classificar estas iniciativas de novas e antigas igrejas evangélicas como “estratégias", pois são concebidas para regular atitudes e práticas em um espaço delimitado - são de fato espaciais, mesmo quando se refere ao ciberespaço. Entretanto, tais estratégias surgem de negociações entre o que as lideranças planejam para a sua juventude (o que implica entender como as lideranças - em geral adultas - compreender o que é ser jovem, muitas vezes no singular), e o que essa juventude tem feito e pensado dentro e fora do espaço da igreja. Por exemplo, em casos como o Fight Night e Reborn Fight, nas quais as representações de lutadores de artes marciais são articuladas ao imaginário de guerreiros cristãos. Ou mesmo na Cristoteca, na qual os jovens católicos podem dançar ao som de artistas evangélicos, mas em um ambiente livre de álcool, drogas e encontros sexuais. Dessa forma, o entendimento dos usos da comunicação não pode ser dissociado dos circuitos em que ela se insere, e das dimensões de celebração, espetáculo e sociabilidade a que estão ligados.

E existem também as táticas dos crentes, que usam a mídia a fim recriar sua tradição em termos de identidade musical, práticas de consumo e de moda, críticas direcionadas a lideranças e inimigos teológicos. No grande espaço da tradição 
evangélica as táticas dos crentes destradicionalizam as instituições, mas criam novas autoridades e novos sentidos para ser evangélico(a), ser cristão(ã).

Os conceitos estratégia/tática são intrigantes em alguns casos, pois, conforme Michel de Certeau, a cultura é um "mofo" que cresce nos interstícios da vida cotidiana. Deixo para o final um exemplo não explorado na sessão anterior: o uso da internet por jovens da Congregação Cristã no Brasil (CCB), uma igreja que sempre proibiu seus membros de consumir quaisquer meios de comunicação desde sua fundação em 1910. Mesmo assim, encontramos vários websites e redes sociais com membros da CCB. A maioria das páginas e dos blogs alerta que não se tratam de páginas oficias da igreja nem agem em seu nome, oferecendo um link para a única declaração oficial da CCB na internet referente a sua proibição ${ }^{13}$.

Curiosamente, existem páginas e comunidades virtuais de membros da CCB que proclamam seu orgulho de pertencer à congregação. Isto é, eles utilizam uma ferramenta proibida, por conta de sua conexão com o "mundo", para reafirmar sua fíliação religiosa institucional, inserindo em seus murais de mensagem petições de oração, agenda de eventos e hinário. Assim como encontramos em algumas comunidades membros que foram criados na igreja, mas atingem a juventude com uma visão crítica dos usos e costumes vigentes na igreja, almejando ressignificar sua identidade e sua experiência como verdadeiros membros da CCB. Utilizando o imaginário cristão, esses membros afirmam que os irmãos que são muito aferrados aos usos e costumes tendem a negligenciar sua fé e o verdadeiro sentido do cristianismo - solidariedade e amor. Portanto, tais cristãos "frios" seriam fariseus e hipócritas, enquanto aqueles que vivem no mundo e usam seus recursos de comunicação estariam muito mais preocupados com a substância da experiência cristã e, não, com a sua aparência.

Por outro lado, as novas igrejas descritas no início deste estudo estariam mais atentas à "aparência" - pois estariam acomodando jovens rejeitados por outras igrejas e mesmo por certos círculos sociais por conta de seu jeito de se vestir, suas escolhas musicais, seu estilo de vida. A disposição de aceitar as mais diferentes parcelas da juventude também cria um espaço no qual a instituição age e regula, por mais "liberais" possam parecer ao ter membros com piercing e tatuagens, metaleiros e góticos, elas também criam limitações aos crentes: a Bola de Neve defende do sexo após o

\footnotetext{
${ }^{13} \mathrm{Cf}$. http://www.congregacaocrista.org.br/. Acessado em 4 de dezembro de 2011.
} 
casamento, condena o tabagismo, o álcool, as drogas. Na Comunidade Golgota, tem tudo isso e mais: pentecostalismo não é bem-vindo. A questão da aparência em oposição à substância nasce de uma visão religiosa, mas podemos nos questionar: tendo em vista tantas ações sociais articuladas tanto pela Igreja Católica quanto pelas igrejas protestantes no passado, estariam ambas negligenciando esse aspecto de atuação, após o retrocesso político e cultural da Teologia da Libertação e do Evangelho Social?

Esse é um ponto a ser explorado em futuras pesquisas: a atuação da juventude ecumênica no início do século XXI, utilizando cada vez mais ativamente as redes sociais e as mídias digitais, é um fato crescente que se une ao coro dos blogueiros descontentes com o neopentecostalismo. Trata-se de algo mais ligado ao chamado protestantismo histórico brasileiro (presbiterianos, metodistas, anglicanos, episcopais, batistas, congregacionalistas), mas como todo fenômeno religioso contemporâneo, não se restringe mais a esse círculo. O último censo revela o crescimento de comunidades evangélicas independentes, que podem no futuro mudar a configuração do campo evangélico brasileiro após anos de crescimento pentecostal.

O que sabemos atualmente é que, segundo o comunicólogo americano Stewart Hoover (2001; 2006), a autonomia religiosa dos indivíduos permite que estes sejam responsáveis pela condução de sua experiência na era contemporânea - no caso brasileiro, desde os anos 1950. A mídia- secular e religiosa - ajuda a acentuar tanto as estratégias de novas e antigas instituições, quanto as táticas dos indivíduos no mercado religioso e cultural. A autonomia traduz-se a partir de diferentes formas: o pragmatismo, a escolha racional, a acolhida comunitária, o sentir-se bem com determinadas práticas, ambientes, pessoas, rituais, textos e discursos. A mídia serve não somente para fazer propaganda destes elementos, mas também serve para que se instruam, saibam mais sobre sua fé, sua tradição; serve para estimular a interação entre seus membros, para criar uma imagem da própria instituição, e de seus fiéis.

Ter consciência destes mecanismos todos nos faz retornar a Certeau, que dedicou "A invenção do cotidiano" ao homem ordinário, visto não como uma vítima da sociedade de consumo, mas um sujeito com potencial criativo. Podemos pensar que esse era uma visão um tanto otimista de Certeau em relação à humanidade, porém, o fato de nos conscientizarmos do nosso potencial criativo é de alguma forma libertador. No caso do nosso tema, essa visão nos permite pensar nos indivíduos não enquanto vítimas de 
instituições religiosas, mas sim enquanto seres criativos, sensíveis, cujas escolhas religiosas estão cada vez mais sujeitas a múltiplas variáveis - busca de solução de problemas emocionais, materiais, físicos, familiares; busca por conforto espiritual; busca por uma comunidade, sociabilidade, amizade. Tantos são os motivos que fazem as pessoas escolher esse ou aquele caminho, quanto são as possibilidades oferecidas pelos canais religiosos existentes.

Saber que a identidade religiosa é um processo em construção é libertador tanto para os indivíduos quanto para as instituições, pois abre o caminho para que ambos repensem o que desejam para cultivar a vida espiritual; é libertador para a instituição pois permite que ela se abra para as demandas de seus membros e estabeleça com eles um diálogo sincero; é libertador para os indivíduos pois permite que eles se abram para o diálogo com outros companheiros de caminhada, estejam eles dentro ou fora da instituição. As estratégias desenvolvidas pelas igrejas e as táticas desenhadas pelos fiéis jovens podem se abrir à experimentação e à criatividade, provocando uma movimentação no campo evangélico que pode tanto perdurar quanto perecer; se a tendência continuar quando esses jovens de 2000 e 2010 envelhecerem, só o tempo - e novas pesquisas - dirão.

É claro que esta é uma conclusão utópica da minha parte, e talvez Certeau não pudesse imaginar que seu trabalho poderia inspirar esse tipo de inferência. Porém, enquanto historiadora cultural das religiões, penso ser este um caminho para se valorizar a diversidade humana, a tolerância e o diálogo, a ser cultivado, a ser re-inventado todos os dias, por todos.

\section{Referenciais}

BELLOTTI, Karina Kosicki. Delas é o reino dos céus: mídia evangélica infantil na cultura pós-moderna do Brasil (1950-2000). São Paulo: Annablume/Fapesp, 2010. - História das Religiões: Conceitos e Debates na Era

Contemporânea. Revista História: Questões \& Debates. N55, jul-dez 2011, pp.13-42. "Media and Christian Youth Groups in Brazil" In FISHERKELLER, JoEllen (org.). FISHERKELLER, JoEllen. (Org.). International Perspectives on Youth Media: Cultures of Production and Education (Mediated Youth) New York: Peter Lang Publishing, 2011, pp. 83-102.

CAMPOS, Leonildo Silveira. Teatro, Templo e Mercado. Vozes/Simpósio Editora/Umesp, Petrópolis, São Paulo, São Bernardo do Campo, 1997.

CARRANZA, Brenda. Renovação Carismática Católica: Origens, mudanças e 
tendências. 2. ed. Aparecida SP: Santuário, 2000.

CERTEAU, Michel de. A invenção do cotidiano - vol.1 - Artes de Fazer. Petrópolis: Vozes, 1998, $9^{a}$ edição.

CHARTIER, Roger. À beira da falésia. Porto Alegre: EdUFRGS, 2003.

CUNHA, Magali. A explosão gospel: um olhar das ciências humanas sobre o cenário evangélico no Brasil. Rio de Janeiro. Mauad X; Instituto Mysterium. 2007

FONSECA, Alexandre Brasil. Os Evangélicos e a Mídia. Rio de Janeiro/UFRJ: Dissertação de Mestrado em Sociologia, 1997.

FREITAS, Marcos Cezar de (org.). História social da infância no Brasil. São Paulo: Cortez, 1997.

FREYRE, Gilberto. Sobrados e Mucambos: decadência do patriarcado rural e desenvolvimento do urbano. São Paulo: Editora Global, 2006 [1936].

HELLAS, Paul; MORRIS, Paul; and LASH, Scott. (eds.) Detraditionalization. WileyBlackwell, 1996.

HOOVER, Stewart M. Religion in the Media Age. New York, London: Routledge, 2006.

"Visual religion in media culture" In: MORGAN, D. \& PROMEY, S. (eds.). Visual Culture in American Religions. Los Angeles: University of California Press, 2001, pp. 146-159.

JENKINS, Henry. A Cultura da Convergência. São Paulo: Aleph, 2009, $2^{a}$ edição.

JUNGBLUT, Airton Luiz. Nos Chats do Senhor: um estudo antropológico sobre a presença evangélica no ciberespaço brasileiro. Tese de Doutorado, PPGAS: Porto Alegre, UFRGS, 2000.

O uso religioso da internet no Brasil. Plura. Revista de

Estudos da Religião,vol.1, n.1., 2010, pp.202-212.

MALUF, Marina e MOTT, Maria Lucia. "Recônditos do mundo feminino" In SEVCENKO, Nicolau. História da Vida Privada - República: da Belle Époque à Era do Rádio. São Paulo: Companhia das Letras, 1998, pp.367-421, vol.3.

MARIANO, Ricardo. Neopentecostais: sociologia do novo pentecostalismo no Brasil. São Paulo: Loyola, 1999.

MCLUHAN, Marshall. Understanding Media: The Extensions of Man. Gingko Press, 2003 [1964].

NOVAES, Regina C. R. "Os jovens, os ventos secularizantes e o espírito do tempo" In: TEIXEIRA, Faustino e MENEZES, Renata. (orgs.). As religiões no Brasil: continuidades e rupturas. Petrópolis: Vozes, 2006, pp. 135-160.

Recebido: 03/04/2014

Received: 04/03/2014

Aprovado: 19/07/2014

Approved: 07/19/2014 